\title{
Experiential Learning, Conditional Knowledge and Professional Development at University of Nairobi, Kenya-Focusing on Preparedness for Teaching Practice
}

\author{
Odundo P. Amolloh ${ }^{1}$, Ganira K. Lilian ${ }^{1} \&$ Kinyua G. Wanjiru ${ }^{1}$ \\ ${ }^{1}$ Department of Educational Communication and Technology, University of Nairobi, Kenya \\ Correspondence: Odundo P. Amolloh, Department of Educational Communication and Technology, University of \\ Nairobi, P. O. Box 30197, Kenya. E-mail: odundopaul@yahoo.com
}

Received: October 15, 2017

Accepted: March 21, $2018 \quad$ Online Published: June 28, 2018

doi:10.5539/ies.v11n7p125

URL: https://doi.org/10.5539/ies.v11n7p125

\begin{abstract}
Experiential learning requires teacher educators to equip trainee teachers with opportunities for effective preparedness in teaching and professional subjects, co-curricular activities and in micro-teaching vital for professional development. The experiential learning opportunities, conditional knowledge, preparedness and performance during teaching practice provide basis for predicting professional competence and success for effective teaching. Conditional knowledge entails application of critical thinking and problem solving skills that demonstrate mastery of theoretical knowledge and professional practice across, content, knowledge, skills and insights. This type of knowledge and skills are developed through experiential learning coupled with effective preparedness for real-class instructional management. However, inadequate preparation in educational courses coupled with improper supervision and feedback impede effective professional development in most universities. The study explored effectiveness of experiential learning and conditional knowledge in trainee teacher preparedness for teaching practice at the University of Nairobi. Experiential Learning Theory formed the framework for this study. A descriptive survey research design was adopted with a population of 78 trainee teachers selected using simple random sampling. Data were gathered through a questionnaire. Finding showed that trainee teachers are adequately prepared for teaching practice. The study recommends proper orientation for trainee teachers to be carried out with effective preparedness that aligns theory to practice.
\end{abstract}

Keywords: conditional knowledge, experiential learning, preparedness, teacher professional development, teaching practice

\section{Introduction}

Experiential learning is a holistic perspective where knowledge is created through transformation of experience. Kolb's (1984), experiential learning cycle provides a holistic approach in which concrete experiences, reflection, abstraction and experimentation ensure an active involvement of trainee teachers during teaching practice. The experiential learning cycle makes it appropriate for trainee teachers to analyze the experience, both during and after teaching practice in order to make meaning from experience and identify what has been learned. Teaching practice as an experiential phase of teacher professional development (Blair, 2016), is successful in learner development when a reliable experiential pedagogical orientation is provided. In this regard, creating appropriate experiential learning opportunities provides trainee teachers with rich and authentic opportunities for developing knowledge as well as skills vital for professional growth. While experiential learning provides a framework for self-regulated learning, (Klug, Gerich, \& Schmitz, 2016), noted that conditional knowledge requires trainee teachers to decide when and why to perform tasks as an integral part of self-regulated learning. Achievement in conditional knowledge therefore depends on effective preparedness on knowing facts and procedures on when and why to employ knowledge. Therefore in instances where trainee teachers are appropriately prepared in professional subjects, co-curricular activities and in micro-teaching, there is a likelihood of increased learner motivation, autonomous learning, enhanced reflection and improved metacognitive skills vital for learner achievement.

Proponents of experiential learning including Dewey (1938), Kurt (1946), and Piaget (1958) contented that no proper acquisition of knowledge is sustainable if the learner is not given opportunities to participate in learning. 
Drawing from this contention, the Government of Kenya through Sessional Paper No. 4 of 2012, on Reforming Education and Training recommended curriculum reforms that foster quality education at all levels of learning by involving learner experiences. Through implementation of this policy, the Constitution of Kenya (2010) and the Ministry of Education (2016), with focus on National Education for sustained development advocated for inclusion of experiential learning strategies in all learning environments and teacher training programmes. In response to this policy, experiential learning which takes place through teaching practice has a clear distinct role in preparing trainee teachers for professional development in Kenya. This is in line with aspirations of Kenya's Vision 2030 for enabling teacher educators to deliver quality education focusing on appropriate pedagogy and learning environments that are interactive, learner-centered and relevant to societal needs. In consequence, the synchronized programme of undergraduate teacher education is practical in all public universities where trainee teachers are exposed to teaching practice in order to develop professional growth.

The University of Nairobi addresses numerous objectives of experiential learning through teaching practice by providing trainee teachers with a range of skills and competences of teaching, preparing daily lesson plans, class management and evaluating learning outcome. Conversely, despite the University's commitment to experiential learning and quality teaching, analysis by Mahulo (2012), showed that there exist a myriad of challenges that affect effective preparation for novice teachers in most teacher training programmes. The analysis further revealed that inadequate preparation in educational courses prior to teaching practice coupled with improper supervision and feedback is an impediment to effective professional development. To achieve proficiency in teaching practice, teacher trainees are required to demonstrate clear and coherent preparedness in teaching and professional subjects, co-curricular activities and in micro-teaching. Further still, Nasimiyu (2017) observed that teacher education programme is narrow in scope, conservative in nature and inappropriate to needs of modern Kenya. The study further indicated that though lecturers and trainee teachers have an optimistic perception about teacher preparation, the duration for preparation is inadequate. Hence, teacher preparation programmes should grant trainee teachers a wide repertoire of skills and opportunities to develop pedagogies in readiness for teaching practice. This is based on the argument that adequate preparedness results in possible efficient application of skills befitting contextual conditions regarding effective teaching which translates into higher learner achievement.

Additional analysis by Ochanji, Ayot, Kamina, Ondigi, and Kimemia (2015), showed that in Kenya, massive expansion on universities in teacher education programmes with huge student enrolments has exerted pressure to both physical and human resources which lower quality of trainee teacher preparation. Adequate teacher preparation demands knowledge on part of the trainee teacher as well as experience of how to put theory into effective practice. While most teacher programmes focus on equipping trainee teachers with skills and knowledge on effective teaching, Koross (2016) noted that how well prepared the teacher trainee is equipped is often unclear. In regard to this argument, knowing what to teach, how to teach and what methods combine to form knowledge and skills that define teaching proficiency. Further still, Prenger, Poortman, and Handelzalts (2017) noted that, limited support for novice teachers hinders knowledge sharing during professional development. In order to address this concern, trainee teachers need a seamless experience from pre-service to in-service that is strategic where knowledge and skills are gradually developed and internalized. When effective preparation is realized, trainee teachers are likely to employ metacognitive strategies to continually reflect upon experiences for professional growth. Therefore, appropriately designed and effectively implemented trainee teacher programmes are key component to successful achievement and institutionalization of professional development. Furthermore, conditional knowledge requires application of critical thinking and problem solving skills that demonstrate mastery of theoretical knowledge and professional practice across, content, knowledge, skills and insights. It is based on this background that the study explored effectiveness of experiential learning and conditional knowledge in trainee teacher preparedness in professional subjects, co-curricular activities, and usefulness of micro-teaching at the University of Nairobi.

\subsection{Experiential Learning and Conditional Knowledge in Teaching Subjects}

Conditional knowledge requires application of critical thinking and problem solving skills that demonstrate deeper mastery of what to teach and how to teach requiring concrete experiences, reflective observation, abstract conceptualization and active experimentation. Effective teaching, Ngware, Ciera, Musyoka, and Oketch (2015) is achieved with proficiency in conditional knowledge of related subjects, mastery of content, proper integration of experimental segments of topics covered which in turn encourages learners to go beyond state of competency goals and achieve academically. Hence, application of experiential learning is ideal within practice tailored to curriculum through teaching basic subjects, lesson planning, structuring of learning objectives and in instructional management.

According to Seebruck (2015), an effective teacher preparation programme produces highly prepared teachers in 
respective teaching subjects who in turn produce better learner achievement than those ill prepared. Based on this observation, trainee teachers require knowledge in teaching subjects, exposure to a wider scope of information, skills as well as practical experience in specific disciplines as foundation for specialized learning. In addition, Ganira and Odundo (2017) examined influence of teacher's knowledge of content on effective use of inquiry-based approach in teaching preschool science in Migori County. Findings from the study illustrated that teachers with background knowledge in Science successfully employed inquiry-based instruction. The analysis proved that even if the approach is good, professional development will not influence inquiry-based method but knowledge of science content will. The study further showed that revealed that content knowledge is strongly related to preparation received for teaching and learner achievement. Unfortunately there are few studies on effectiveness on specific-subject preparation that novice teachers receive in teacher preparation programmes.

\subsection{Experiential Learning, Conditional Knowledge and Usefulness of Professional Courses}

Professional qualification focuses on developing application and contextualization of knowledge and skills in specialized subjects to make learning relevant. Success of teaching specific subjects is realized (Adeyemi, 2010), when learners eventually demonstrate acquired professional knowledge and skills in line with subjects taught with positive influence on academic achievement. Teachers conversant in conditional knowledge and experiential expertise are more likely to be proficient in pedagogical content knowledge, problem solving skills and positively adapt to diverse learners. Further, in a study that examined teacher qualification influence on student academic performance in science mathematics (SMT) and technology subjects, (Musau,\& Abere, 2015), found out that majority of SMT subjects teachers were trained graduates, and most had attended in-service or refresher courses which resulted in improved learner achievement. Hence, teachers with enriched conditional knowledge in specialized subjects are likely to; realize professional ability, enhanced confidence, leadership skills and motivation which boost learner achievement.

In a study on preparing novice teachers for requirement of teaching and professional development in Algeria, Mounira (2013) observed that university courses provide only theoretical background on teaching profession without stressing its pedagogical implications therefore not preparing future teachers adequately. If teacher educators can support trainee teachers in preparing in professional subjects, there are high chances of creating authentic practice-based programmes within subject-oriented field experiences that demonstrate growth in trainee teacher competence. Given that educational experiences emphasize rote memorization, sectionalized knowledge and peripheral understanding of content, (Sarabdeen, 2013), pointed out that experiential learning meets challenges of preparing and supporting trainee teachers in applying inventive approaches ideal for professional subjects. Based on this observation, trainee teachers should be conversant with content and pedagogy, including instructional materials that support particular topics being conveyed as well as applying and reflecting on new practices.

\subsection{Experiential Learning, Conditional Knowledge and Usefulness of Co-Curricular Activities}

Co-curricular activities are programs and learning experiences that compliment and mirror academic curriculum through creativity, enthusiasm, energy and positive thinking. (Marais, 2011), asserted that co-curricular activities develop trainee teacher's abilities in establishing and defending own stand on various situations with respect to other people' positions and how to work together to a consensus. Adequate preparation in co-curricular activities therefore helps trainee teachers in maximizing quality instruction, maintaining clear instruction and in developing proper perception of class events. According to Antovska and Kostov (2016), development of skills and knowledge in handling co-curricular activities is a prerequisite in teacher trainee preparation. Appropriate skills in co-curricular activities enhance quality of teaching/learning process through diverse aspects including emotional, social, moral and aesthetic development. Therefore, trainee teachers with appropriate preparedness in co-curricular activities, guide learners in; organizing and presenting activities, developing skills, cooperating and coordinating in various class situations which in turn enhance leadership among learners.

However, according to Kigwilu, Jumba, and Wambua (2016), the curriculum for co-curricular activities is bound to fail in efficiency if not aligned with experiential lessons that are learner-centred and by making it a theoretical process that enhances learner achievement. Therefore, trainee teacher need to be acquainted with the nature and challenges of co-curricular activities of respective school to foster commitment to task in guiding and coaching learners. In China, Zhang and Tang (2017) explored the relationship among five types of extracurricular science activities, learning interests, academic self-concept, and science achievement. The study observed that students who participated in extracurricular science activities had a positive and indirect influence on science achievement through the mediating variables of learning interests and academic self-concept. However, there were opportunity gaps between different groups of students in terms of school location, family background, and especially the 
mother's education level. In this regard, trainee teachers need to focus on ways in which knowledge is imparted through co-curricular activities, since prior knowledge influences learning by building useful knowledge structures that require effort and purposeful activities.

\subsection{Experiential Learning, Conditional Knowledge and Usefulness of Microteaching}

Microteaching is an experiential skill training technique (Remesh, 2013), that employs real teaching situation for developing skills and helps in getting deeper knowledge regarding art of teaching. Through concrete experiences, reflective observation, abstract conceptualization and active experimentation, skills acquired in microteaching enhance problem-solving, critical thinking, questioning and reflective thinking which evaluate intensity of conditional knowledge of trainee teachers. Conditional knowledge plays an essential part in self-regulated learning which requires trainee teachers to apply prior knowledge in performing a given task. (Ralph, 2014), indicated that conditional knowledge is experiential in nature and essential for guiding on leaner-centered teaching which is to be achieved through micro-teaching. In instances where microteaching is effective, trainee teachers acquire self-confidence, enhanced self-esteem and are able to have immediate feedback for improvement purposes. Hence, application of micro-teaching skills including critical thinking and problem solving alongside instructional strategies are critical for trainee teachers to acquire knowledge for effective teaching.

According to Fischer (2011), conditional knowledge interrogates quality of instruction acquired during preparation which can be assessed in microteaching lessons. For trainee teachers to be effective in preparation there should be consideration of both pedagogical skills and personal skills which are tested during microteaching lessons as a way of building confidence in conditional knowledge and class management. In Nigeria, Sa'ad, Sabo, and Abdullahi (2015) found out that microteaching is useful in improving teaching skills, classroom management and confidence of trainee teachers. Therefore, recommended micro-teaching to be maintained by undergraduate teacher training programmes and be made a pre-requisite to teaching practice. Given the usefulness of micro-teaching, teacher educators should build awareness and sensitivity to trainee teachers about usefulness of micro-teaching.

\section{Statement of the Problem}

Experiential learning requires teacher educators to equip trainee teachers with adequate knowledge and skills to utilize concrete experiences, reflective observation, abstract conceptualization and active experimentation for professional growth. The experiential learning opportunities coupled with conditional knowledge, preparedness and performance during teaching practice provide basis for predicting professional competence and success for effective teaching. However, even though the University supports experiential learning and quality teaching, studies have shown that there exist a myriad of challenges that affect effective preparation for novice teachers in most teacher training programmes. Mahulo (2012) found inadequate preparation in educational courses prior to teaching practice as well as improper supervision and feedback as impediment to effective professional development. To achieve proficiency in teaching practice, teacher trainees should demonstrate clear and coherent preparedness in teaching and professional subjects, co-curricular activities and in micro-teaching. Further still, Nasimiyu (2017) observed that teacher education programme is narrow in scope, conservative and conventional in nature, with less emphasis on the needs of modern Kenya. The study further indicated that lecturers and trainee teachers have a good perception about teacher preparation, but feel the present duration or teacher preparation programme is inadequate. Consequently teacher preparation programmes should grant teacher trainees a wide repertoire of skills and opportunities to develop pedagogies for effective preparedness for teaching practice. With adequate preparedness in teaching and professional subjects, co-curricular activities and in micro-teaching there is a likelihood of increased learner motivation, autonomous learning, enhanced reflection and improved metacognitive skills.

\section{Purpose and Objectives}

The purpose of this study is to explore extent to which experiential learning and conditional knowledge is adopted by trainee teachers during teaching practice. The objective was to determine the influence of experiential learning and conditional knowledge on trainee teacher preparedness during teaching practice.

\section{Theoretical Framework}

Experiential Learning Theory by Kolb (1984) formed the basis for this study. Kolb's experiential learning theory draws on intellectual work of Dewey (1938); reflective thought and action (Kurt, 1946); action learning and (Piaget, 1958); cognitive development. Kolb's theory emphasizes experience as crucial in the learning process. The theory possesses structured factors for exploring learning experiences as trainee teachers go through stages of professional growth. Kolb's (1984) concrete experiences, reflective observation, abstract conceptualization and active experimentation are imperative throughout stages of teacher professional development. As trainee teachers 
develop and progress on instructional methodologies, individual experiences are imparted by support from university lectures, regular and collaborating teachers as well as school principals. In order to navigate through Kolb's cycle of learning, trainee teachers require appropriate preparedness and conditional knowledge in teaching and professional subjects, co-curricular activities and in micro-teaching that will translate into professional development.

According to (Darling- Hammond, 2010), novice teachers go for teaching practice with inadequate experience of pedagogy and class management. In this regard, learning cycle in which experiential learning takes place gives trainee teachers repetitive series of the learning experiences. In addition, trainee teachers engage in formative assessment during teaching practice, in which challenges encountered daily in instructional management are identified. In an attempt to solve these challenges, trainee teacher goes through experimenting with possible solutions, reflect on resolutions, correct errors and continue with the cycle with consecutive attempts to arrive at possible solutions for effective teaching. These measures undertaken by trainee teachers reflect on components and stages in Kolb' experiential learning theory.

During the concrete stage of professional development, the trainee teacher encounter a new experience of realclass instruction, may undergo challenges and build schema that emanate from the experience. To overcome negative experiences during this stage, the trainee teacher requires metacognitive skills, reflect and assess self-behavior and learn to effectively interact with learners. When this is achieved, the trainee teacher enters abstract conceptualization stage that requires additional resources, support and scaffolding from university assessors, regular and collaborating teachers as well as school principals. With enhanced confidence, the trainee teacher enters active experimentation and goes through the process of experiential learning with self-assurance and esteem that transforms into effective professional development. Therefore in instances where trainee teachers are appropriately prepared in teaching and professional subjects, co-curricular activities and in micro-teaching, learners are likely to acquire increased learner motivation, autonomous learning, enhanced reflection and improved metacognitive skills.

\section{Conceptual Framework}

The conceptual framework in this study illustrates connection between independent, dependent and extraneous variables. According to McGaghie et al. (2001), a conceptual framework sets the stage for representation of objectives that drive the investigation being reported based on the statement of the problem. Teaching practice as an experiential phase of teacher professional development is successful when there is adequate preparedness in teaching and professional subjects, co-curricular activities and in microteaching. Preparedness in teaching subjects therefore gives trainee teachers opportunities for effective lesson planning, structuring learning objectives and in instructional management. Explicit preparedness in professional subjects enables trainee teachers to develop pedagogical content knowledge, problem solving skills as well as an adaptation to diverse needs of learners. Given the importance of co-curricular activities, adequate preparation is critical in maximizing quality of instruction, maintaining clear instruction and a fine perception of class events. In addition, microteaching when adequately implemented, promotes self-confidence, self- esteem and immediate feedback. If trainee teachers prepare adequately for teaching practice, learners are likely to experience increased learner motivation, autonomous learning, enhanced reflection and improved metacognitive skill which in turn lead to enhanced learning. 


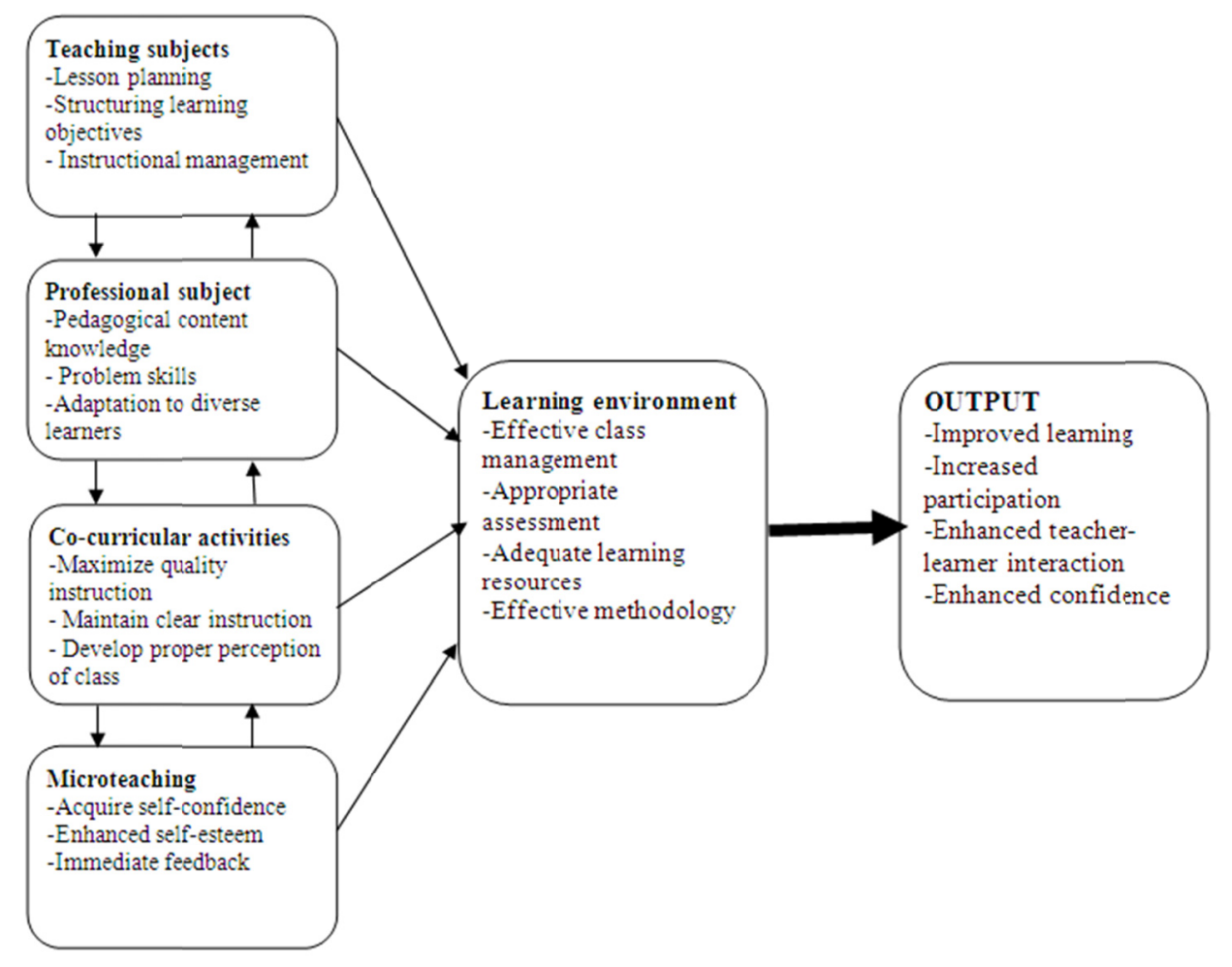

Figure 1. Conceptual Framework based on experiential learning, conditional knowledge and teacher trainee professional development

\section{Methodology}

The study adopted a descriptive survey research design. Descriptive survey design explains the position of affairs as it exists (Kombo \& Tromp, 2009). Description is conducted to influence improvement of a situation. The target population of the study was 68 teacher trainees from University of Nairobi distributed in 17 Counties in Kenya. The sample of the study was 68 teacher trainees ( 44 males and 24 females) on teaching practice randomly selected from 17 Counties used by external moderators. The schools in which the teacher trainees were undertaking teaching practice were sampled. A questionnaire was used to collect data on the level of preparedness offered to the teacher trainees while on internship by collaborating partners. Ethical considerations regarding informed consent and confidentiality were upheld. Analysis of data involved the use of descriptive and inferential statistics. More specifically, graphs, frequencies and percentages were used in comparisons across categories. The Chi-square Statistic and Pearson's Product Moment Correlation Coefficient were used in making statistical inferences about relationships among variables.

\section{Findings}

\subsection{Characteristics of the Respondents and Schools}

There were a total of 68 respondents out of whom 44 (64.7\%) were male and 24 (35.3\%) were female drawn from 68 schools where the teacher trainees were undertaking teaching practice and distributed in 17 Counties. The response rate was $100 \%$ with distribution of respondents based on concentration of trainee teachers during teaching practice and the expanse of the region. Nairobi County had the highest number of respondents followed by Mombasa and Homabay. Murang'a and Uasin had the lowest number of respondents given the fewer students who chose to practice teaching in the respective areas.

\subsection{Preparation in Teaching Subjects}

Teaching/learning process requires experimentation with assurance, confidence and esteem that transforms into effective professionalism. Respondents were asked to indicate preparedness in teaching subjects, whose findings are shown in Table 1. 
Table 1. Preparation in subjects

\begin{tabular}{ccc}
\hline Response & Frequency & Percent \\
\hline Neutral & 1 & 1.5 \\
Well & 14 & 20.6 \\
Very well & 53 & 77.9 \\
Total & 68 & 100.0 \\
\hline
\end{tabular}

Table 1 presents responses elicited by teacher trainees who were asked whether they were adequately prepared in teaching subjects. Majority of respondents, 53 (77.9\%) felt that the quality of preparation received was utterly adequate for professionalism as well as learner achievement. This positive responds was as a result of effective curriculum that enabled teacher trainees to prepare adequately in teaching basic subjects, lesson planning, structuring of learning objectives and in instructional management. On the other hand, $14(20.6 \%)$ found the preparation satisfactory while $1(1.5 \%)$ out of the 68 , was rather satisfied with the preparation received. These findings concur with a study carried out in Kenya on influence of teacher's knowledge of content on effective use of inquiry-based approach in teaching preschool science (Ganira, \& Odundo, 2017), that professional development will not influence learning, but knowledge of content will.

\subsection{Preparation in Professional Courses}

Professional qualification focuses on developing application and contextualization of knowledge and skills in specialized subjects to make learning relevant. In regard to preparedness in professional courses, the respondents were to determine the level of productivity acquired during training. The results of the findings are indicated in Table 2 .

Table 2. Preparation in professional courses

\begin{tabular}{ccc}
\hline Response & Frequency & Percent \\
\hline Neutral & 1 & 1.5 \\
Well & 18 & 26.5 \\
Very well & 49 & 72.1 \\
Total & 68 & 100.0 \\
\hline
\end{tabular}

According to the findings in Table 2, Out of the 68 respondents, $1(1.5 \%)$ reported that preparation was insignificant while $18(26.5 \%)$, termed the preparation favorable. Further, $49(72.1 \%)$, expressed uttermost satisfaction in preparation. The trainee teachers were conversant with content and pedagogy, including instructional materials that supported particular topics being conveyed and also applied and reflected on new practices. These findings conquer with results by Musau and Abere (2015), who reported that appropriate training in in professional courses result into high learner achievement.

\subsection{Preparation in Co-Curricular Activities}

Co-curricular activities develop trainee teacher's abilities in establishing and defending own stand on various situations with respect to other people' positions and ways of working together to a consensus. Study findings in Table 3 and Figure 2 represent views of teacher trainees on preparation in co-curricular activities.

Table 3. Preparation in co-curricular activities

\begin{tabular}{ccc}
\hline Response & Frequency & Percent \\
\hline Very poorly & 1 & 1.5 \\
Poorly & 3 & 4.4 \\
Neutral & 14 & 20.6 \\
Well & 19 & 27.9 \\
Very well & 31 & 45.6 \\
Total & 68 & 100.0 \\
\hline
\end{tabular}

From the analysis in Table 3, out of 68 respondents, $1(1.5 \%)$ expressed discontent with the training offered on co-curricular activities, while 3 (4.4\%), indicated less satisfaction compared to $14(20.6 \%)$ who were neutral on the 
quality of preparation received. On the other hand, $19(27.9 \%)$ were satisfied with the co-curricular training while majority, 31(45.6\%) were completely contented with the training. This responds was based on the premise that appropriate skills in co-curricular activities enhance quality of teaching/learning process through diverse aspects including emotional, social, moral and aesthetic development. In line with findings of (Zhang \& Tang, 2017), indicated that co-curricular activities have positive and indirect influence on learners' achievement through mediating variables of learning interests and academic self-concept.

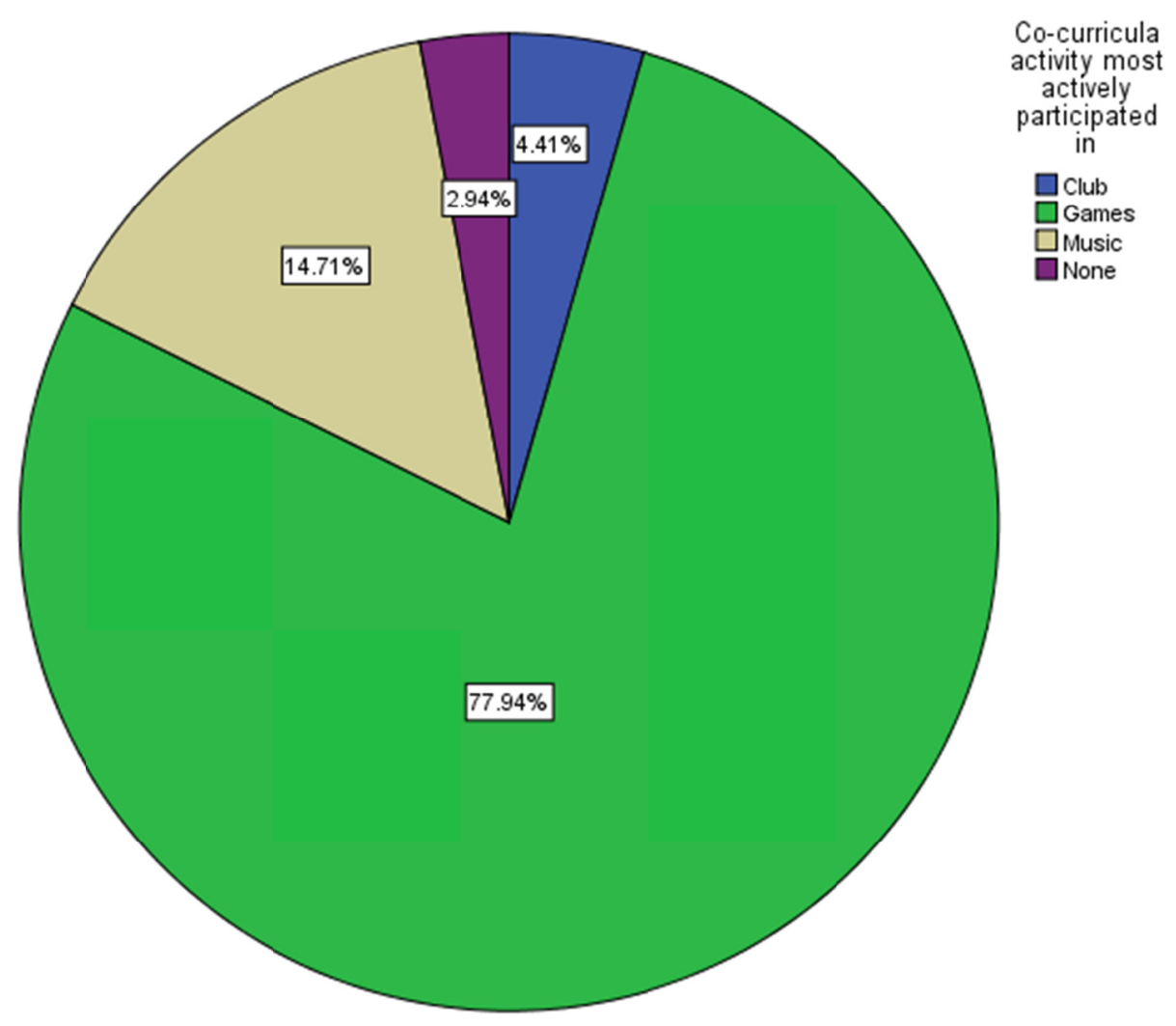

Figure 2. Co-curricular activities most actively participated in.

Findings Figure 2, showed that games took up $77.94 \%$ of the co-curricular activities most participated. Games are the most enjoyed given that it is a hands-on activity that relies on direct experience. As indicated by Dewey (1938), all genuine learning comes from experience. During games, learners engage in concrete experience, reflective observation, abstract conceptualization and active experimentation for effective learning to occur. Participation in music took up to $14.715 \%$, based on the premise that it is an authentic art learnt skill that develops active learning drawing from learner experiences and provides mechanisms connecting knowledge to future opportunity. Clubs occupied $4.41 \%$ of co-curricular activities in schools and was not considered critical since some administrations perceived it time wasting. Further still, schools comprising $2.94 \%$ took no interest in co-curricular activities but would rather spend time set for games for to revise course work and other examinable disciplines.

\subsection{Usefulness of Microteaching}

Microteaching is useful in improving teaching skills, classroom management and confidence among trainee teachers. Teacher trainees were asked whether microteaching was useful in preparation for teaching practice. Findings are shown in Table 4. 
Table 4. Usefulness of microteaching

\begin{tabular}{ccc}
\hline Response & Frequency & Percent \\
\hline Not useful & 2 & 2.9 \\
Useful & 13 & 19.1 \\
Very useful & 53 & 77.9 \\
Total & 68 & 100.0 \\
\hline
\end{tabular}

Findings from Table 4 revealed that cumulatively out of 68 respondents, 53 (77.9\%) felt that microteaching played a core role in perfecting teaching skills and were completely contented. The respondents further indicated that, application of micro-teaching skills including critical thinking and problem solving alongside instructional strategies are critical for developing knowledge for effective teaching. Additionally, $13(19.1 \%)$ found microteaching effective but not with very much impact to the perfection skills whereas $2(2.9 \%)$ felt that the technique was not relevant by any means and would prefer peer teaching. These results echo findings by Sa'ad, Sabo, and Abdullahi (2015), who observed that microteaching is useful in improving teaching skills, classroom management and confidence of teacher trainees.

\section{Conclusion}

The problem of effective teacher training programmes has always been one of the challenges facing teacher educators. To address this concern, the University of Nairobi addresses numerous objectives of experiential learning through teaching practice by providing trainee teachers with a range of skills and competences of teaching, preparing daily lesson plans, class management and evaluating learning outcome. Trainee teachers indicate that the University adequately prepared them for teaching practice. Preparation in teaching subjects and professional courses, co-curricular activities and micro-teaching encouraged trainee teachers' orientation towards teaching and in instructional management. However, there is need for more research into the nature of trainee teacher's conditional knowledge and the relationship between knowledge structure and professional development so as to find ways effective to better knowledge and promote professional development.

\section{Recommendations}

- Sustained quality preparation for teaching practice requires permanent institutional commitment to government policies that support quality teaching and professional development.

- Quality teaching policies should be designed reliably at universities and at individual level so that course work is appropriately aligned to practice.

- The government should enact policies that provide professional development that responds to the educational goals of the institution, reflecting pedagogical competencies required for quality teaching.

- Teacher preparation programmes should grant teacher trainees a wide repertoire of skills and opportunities to develop pedagogies for effective preparedness for teaching practice.

- Teacher educators should engage in a collaborative process to identify pedagogical competencies that trainee teachers require to deliver quality teaching and learning.

- Trainee teachers need a seamless experience from pre-service to in-service that is strategic where knowledge and skills are gradually developed and internalized.

- Further research is needed in order to generate more information on how to improve quality of teaching practice.

\section{References}

Adeyemi, B. (2010). Teacher Related Factors as Correlates of Pupils Achievement in Social Studies in South West Nigeria. Electronic J. Res. Educ. Psych., 8(1), 313-332.

Antovska, M. A., \& Kostov, B., (2016). Teachers, Students and Extracurricular Activities in Primary Education. International Journal of Cognitive Research in Science, Engineering and Education (IJCRSEE), 4(1), 49-53. https://doi.org/10.5937/IJCRSEE1601049A

Blair, D. J. (2016). Experiential learning for teacher professional development at historic sites. Journal of Experiential Education, 39(2). https://doi.org/10.1177/1053825916629164

Darling-Hammond, L., (2010). Teacher Education and the American Future. Journal of Teacher Education 61(1-2), 35-47. https://doi.org/10.1177/0022487109348024 
Dewey, J. (1938). Experience and education. New York, NY: Kappa Delta Pi.

Fischer, M. J. (2011). Interracial contact and changes in the racial attitudes of white college students. Soc Psychol Educ., 14, 547-574. https://doi.org/10.1007/s11218-011-9161-3

Ganira K. L., \& Odundo P. A., (2017). Influence of Teacher's Knowledge of Content on Effective use of Inquiry-Based Approach in Teaching Preschool Science in Migori County, Kenya. Donnish Journal of Educational Research and Reviews, 4(1), 001-007. Retrieved from http://www.donnishjournals.org/djerr

Kigwilu, C. P., Jumba W. A., \& Wambua, J. M. (2016). Challenges Facing The Effective Implementation Of Artisan and Craft Courses in Catholic Sponsored Community Colleges in Nairobi, Kenya. IOSR Journal of Research \& Method in Education (IOSR-JRME).

Klug, J., Gerich, M., \& Schmitz, B., (2016). Can teachers' diagnostic competence be fostered through training and the use of a diary? Journal for educational research online, 8(3), 184-206.

Kolb, D. A. (1984). Experiential learning: Experience as the source of learning and development. Englewood Cliffs, NJ: Prentice Hall.

Kombo, D., \& Tromp, L. (2009). Proposal and Thesis Writing: An Introduction. Pauline Publications Africa, Nairobi.

Koross, R. (2016). The Student Teachers' Experiences during Teaching Practice and Its Impact on their Perception of the Teaching Profession. IRA International Journal of Education and Multidisciplinary Studies, 5(2), 76-85. https://doi.org/10.21013/jems.v5.n2.p3

Lewin, K. (1946) Action research and minority problems. Journal of Social Issue, 2(4), 34-46. https://doi.org/10.1111/j.1540-4560.1946.tb02295.x

Mahulo, P. (2012). Influence of Teacher Training on the Performance of Students in Mixed Secondary Schools in Gem District, Kenya (Unpublished thesis in Business Administration). University of Nairobi, Kenya.

Marais, P. (2011). The Significance of Student Teachers' Involvement in Co-Curricular Activities. International Journal for e-Learning Security (IJeLS), 1(2), 81-88. https://doi.org/10.20533/ijels.2046.4568.2011.0010

Mcgaghie, W., Bordage, G., \& Shea, J. A., (2001).Problem Statement, Conceptual Framework, and Research Question. Academic Medicine, 76, 923-924. https://doi.org/10.1097/00001888-200109000-00021

Ministry of Education Science and Technology. (2016). Education for Sustainable Development Implementation Guidelines.

Mounira, M. (2013). Preparing Novice Teachers for the Requirements of Teaching Professional Development (Unpublished in master fegree in Sciences of Language). Mohammed Kheider University-Biskra, Algeria.

Musau, L. M., \& Abere, M. J., (2015). Teacher qualification and students' academic performance in science mathematics and technology subjects in Kenya. Int. J. Educ. Admin. Pol. Stud., 7(3), 83-89. https://doi.org/10.5897/IJEAPS2014.0386

Nasimiyu, G. (2017). Preparation of Teacher-Trainees in Pedagogy in Kenyan Universities. Journal of Education and Practice, 8(13), 28-34.

Ngware, M. W., Ciera, J., Musyoka, P. K., \& Oketch, M. (2015). Quality of teaching mathematics and learning achievement gains: Evidence from primary schools in Kenya. Educational Studies in Mathematics, 89(1), 111-131. https://doi.org/10.1007/s10649-015-9594-2

Ochanji, K. M., Ayot, H. O., Kamina, P. A., Ondigi, S., \& Kimemia, J. N., (2015).Improving Student Teaching for Quality Teacher Preparation: A Kenyan University Case. African Journal of Teacher Education, 4(1), 1-17. https://doi.org/10.21083/ajote.v4i1.3034

Piaget, J. (1958). The growth of logical thinking from childhood to adolescence. AMC, 10, 12.

Prenger, R., Poortman, C. L., \& Handelzalts, A. (2017). Factors influencing teachers' professional development in networked professional learning communities. Teaching and Teacher Education, 68, 77-90. https://doi.org/10.1016/j.tate.2017.08.014

Ralph, E. G. (2014). The Effectiveness of Microteaching: Five Years' Findings. International Journal of Humanities Social Sciences and Education (IJHSSE), 1(7), 17-28.

Remesh, A. (2013). Microteaching, an efficient technique for learning effective teaching. Journal of Research in Medical Sciences, 18(2), 158-163. 
Republic of Kenya. (2007). Vision 2030. Nairobi. Government printer.

Republic of Kenya. (2010). The Constitution of Kenya. Nairobi, Government printer.

Republic of Kenya. (2012). Sessional paper No. 4 of 2012 on Reforming Education and Training. Nairobi, Ministry of Education, Science and Technology, Government Press.

Sa'ad, T. U., Sabo, S., \& Abdullahi, A. D. (2015). The Impact of Micro-Teaching on the Teaching Practice Performance of Undergraduate Agricultural Education Students in College of Education, Azare. Journal of Education and Practice, 6(26), 109-115.

Sarabdeen, J. (2013). Learning styles and training methods. IBIMA Communications, 2013, 1-9. https://doi.org/10.5171/2013.311167

Seebruck, R. (2015). Teacher Quality and Student Achievement: A Multilevel Analysis of Teacher Credentialization and Student Test Scores in California High Schools. McGill Sociological Review, 5, 1-18.

Zhang, D., \& Tang, X. (2017). The influence of extracurricular activities on middle school students' science learning in China. International Journal of Science Education, 39(10), 1381-1402. https://doi.org/10.1080/09500693.2017.1332797

\section{Copyrights}

Copyright for this article is retained by the author(s), with first publication rights granted to the journal.

This is an open-access article distributed under the terms and conditions of the Creative Commons Attribution license (http://creativecommons.org/licenses/by/4.0/). 